\title{
Circumferential Supracrestal Fiberotomy
}

National Cancer Institute

\section{Source}

National Cancer Institute. Circumferential Supracrestal Fiberotomy. NCI Thesaurus. Code C101206.

A surgical procedure to prevent rotational relapse of teeth after an orthodontic treatment; the epithelial attachment surrounding the involved teeth is severed. 